Review

\title{
Circular RNA as an Epigenetic Regulator in Chronic Liver Diseases
}

\author{
Xianhui Zeng ${ }^{1,2} \mathbb{D}$, Xianglei Yuan ${ }^{2}$, Qiuyu Cai ${ }^{1,2}$, Chengwei Tang ${ }^{1,2}$ and Jinhang Gao ${ }^{1,2, *}$ \\ 1 Lab of Gastroenterology and Hepatology, West China Hospital, Sichuan University, No. 1, 4th Keyuan Road, \\ Chengdu 610093, China; ruading@163.com (X.Z.); caiqiuyu97@163.com (Q.C.); shcqcdmed@163.com (C.T.) \\ 2 Department of Gastroenterology, West China Hospital, Sichuan University, Chengdu 610041, China; \\ yuanxianglei94@163.com \\ * Correspondence: jinhang@wchscu.cn; Tel.: +86-28-851-640-11; Fax: +86-28-855-829-44
}

check for updates

Citation: Zeng, X.; Yuan, X.; Cai, Q.; Tang, C.; Gao, J. Circular RNA as an Epigenetic Regulator in Chronic Liver Diseases. Cells 2021, 10, 1945. https://doi.org/10.3390/cells 10081945

Academic Editors: Heather Francis and Alexander E. Kalyuzhny

Received: 12 May 2021

Accepted: 28 July 2021

Published: 30 July 2021

Publisher's Note: MDPI stays neutral with regard to jurisdictional claims in published maps and institutional affiliations.

Copyright: (C) 2021 by the authors. Licensee MDPI, Basel, Switzerland. This article is an open access article distributed under the terms and conditions of the Creative Commons Attribution (CC BY) license (https:// creativecommons.org/licenses/by/ $4.0 /)$.

\begin{abstract}
Circular RNA (circRNA) is a type of non-coding RNA characterized by a covalently closed continuous loop. CircRNA is generated by pre-mRNA through back-splicing and is probably cleared up by extracellular vesicles. CircRNAs play a pivotal role in the epigenetic regulation of gene expression at transcriptional and post-transcriptional levels. Recently, circRNAs have been demonstrated to be involved in the regulation of liver homeostasis and diseases. However, the epigenetic role and underlying mechanisms of circRNAs in chronic liver diseases remain unclear. This review discussed the role of circRNAs in non-neoplastic chronic liver diseases, including alcoholic liver disease (ALD), metabolic-associated fatty liver disease (MAFLD), viral hepatitis, liver injury and regeneration, liver cirrhosis, and autoimmune liver disease. The review also highlighted that further efforts are urgently needed to develop circRNAs as novel diagnostics and therapeutics for chronic liver diseases.
\end{abstract}

Keywords: circular RNA; epigenetics; alcoholic liver disease; metabolic-associated fatty liver disease; nonalcoholic fatty liver disease; nonalcoholic steatohepatitis; hepatitis; liver regeneration; liver cirrhosis; autoimmune liver disease

\section{Introduction}

The liver is a critical organ for humans. It is composed of hepatocytes, biliary epithelial cells (cholangiocytes), hepatic stellate cells (HSCs), Kupffer cells, mast cells, and liver sinusoidal endothelial cells (LSECs). These cells cooperatively regulate hepatic function in numerous physiological processes, including glucose metabolism, lipid and cholesterol homeostasis, maintenance of energy balance, blood volume regulation, immune responses, and detoxification [1,2]; intercellular communication also contributes to the pathogenesis of liver diseases [3-5]. The liver has a powerful and unique regenerative capacity to maintain the constant size required for body homeostasis, regardless of injury [6,7]. However, various pathogenic agents can damage the liver, resulting in acute or chronic liver disease, such as alcoholic liver disease (ALD), metabolic-associated fatty liver disease (MAFLD), viral hepatitis, hepatocellular carcinoma (HCC), and their complications [8,9]. Liver cirrhosis accounts for approximately one million deaths worldwide annually [10]. The leading causes of cirrhosis in Western countries are alcohol and MAFLD, whereas viral hepatitis B is the main cause in China and other Asian countries [8]. However, the pathogenesis of liver diseases is still not fully understood.

Epigenetic research has accelerated rapidly in the past two decades, and achievements in epigenetics have advanced our knowledge of the pathogenesis of liver diseases [11-13]. In addition, epigenetic modifications have a significant impact on regulating gene expression and occurrence, and the development of diseases [14]. The major carriers of epigenetic information include non-coding RNAs, DNA methylation, histone acetylation, heterochromatin components, and polycomb proteins [15]. 
Among non-coding RNAs, microRNA (miRNA), long non-coding RNA (lncRNA) and circular RNA (circRNA) are the most well-studied non-coding RNAs. miRNAs are non-coding RNAs of only 20-22 nucleotides in length; they repress gene expression by the RNA-induced silencing complex (RISC) [16]. A single miRNA can correspond to many different mRNAs, whereas a single mRNA is regulated by multiple miRNAs [17]. IncRNAs are considered to be longer than 200 nucleotides, which is distinctly different from mRNAs, miRNAs, small nuclear RNAs (snoRNAs) and tRNAs. They are able to regulate gene expression at the level of chromatin modification, transcription and post-transcriptional processing through a diversity of mechanisms $[16,18]$. The ability of lncRNAs to regulate associated protein-coding genes might contribute to many diseases. The competitive endogenous RNA (ceRNA) hypothesis is a theory about lncRNA function that is gaining significant attention; it states that competition for miRNA binding sites regulates the expression of a target gene. The role of IncRNA in chronic liver diseases has previously been described and is not the focus of this review [19-22].

circRNAs are characterized by a covalently closed continuous loop [23]. They have the advantages of stability, conservation, and tissue specificity [24], generated by pre-mRNA through back-splicing (Figure 1).

a

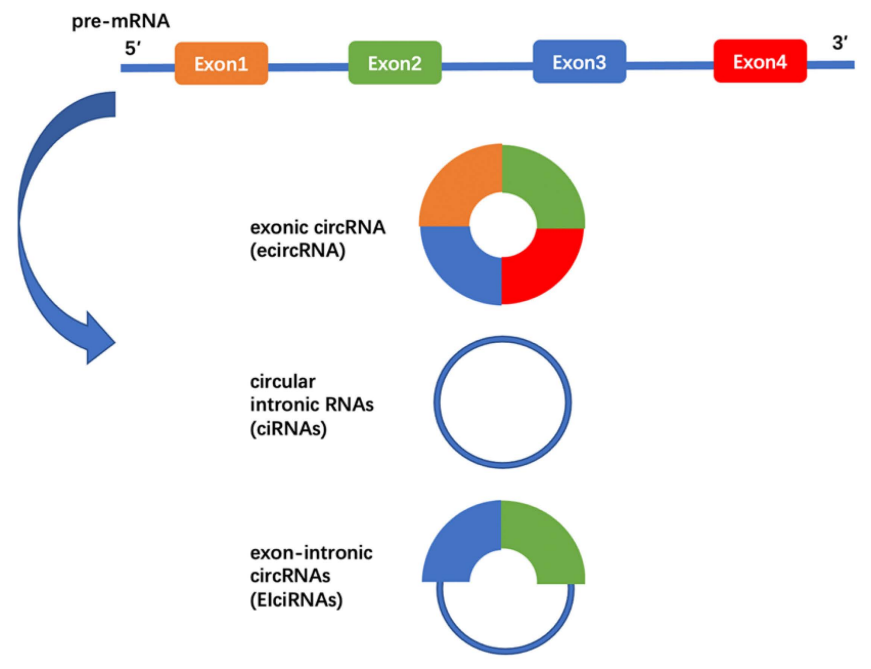

b

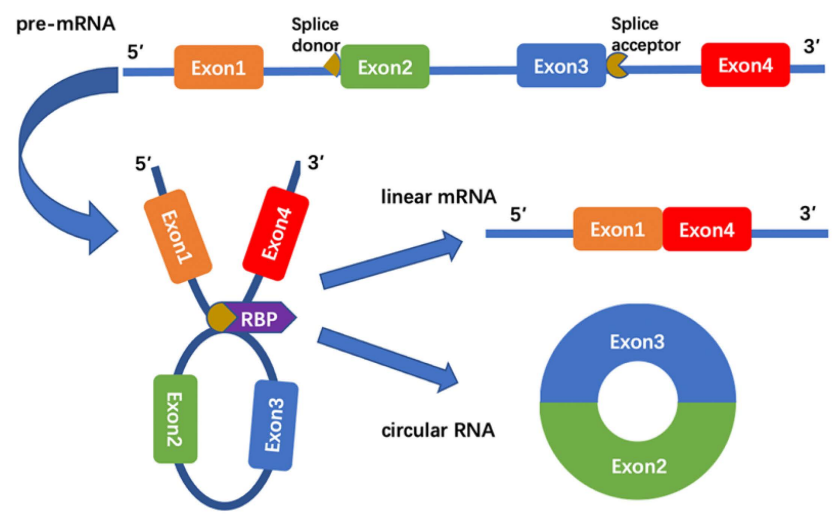

Figure 1. Formation of circRNAs. (a) Three types of circRNAs according to their sources of premRNA. (b) RNA-binding protein (RBP) induces circulation. Circular exons are generated by premRNA through back-splicing between the splice donor site of a downstream exon (the $5^{\prime}$ end of exon 2) and the splice acceptor site of an upstream exon (the $3^{\prime}$ end of exon 3). This event can be mediated by RBPs or specific sequence elements, resulting in the production of a circular RNA and a linear RNA. Blue lines represent introns. 
Degradation of circRNAs cannot be achieved through many classical RNA degradation pathways. They might be eliminated from cells by exocytosis [23-25]. Enclosing circRNAs or circRNA complexes in vesicles and releasing them into the extracellular space is a way to move circRNAs out of the cytoplasm. However, with the protection of vesicles, circRNAs or circRNA complexes can reach other cells or tissues to act as messenger molecules or to fulfill other unknown functions [23]. The degradation of circRNA theoretically involves endonuclease. A recent study found that the N6-methylation of adenosine $\left(\mathrm{m}^{6} \mathrm{~A}\right)$ modification facilitates the recruitment of endonucleases, affecting the degradation of circRNAs via a YTHDF2-HRSP12-RNase P/MRP axis [26].

circRNAs act through several mechanisms (Figure 2), including: (1) miRNA sponges or ceRNA mechanisms [16], which alleviate the inhibitory effects of miRNAs on target genes, thereby increasing the levels of the target genes [27]; (2) protein sponge, such as sponging RNA-binding protein components (RBPs); (3) regulating the expression of a parental gene; and (4) translating into peptides [24,28,29].

a

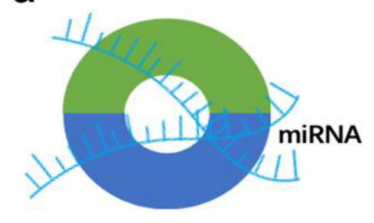

b

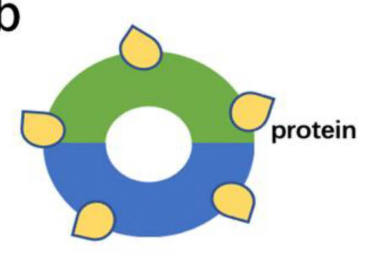

C

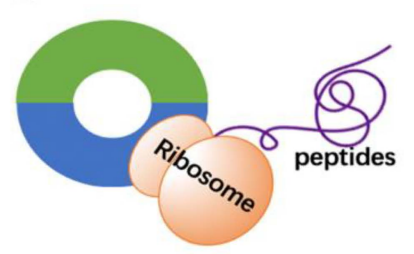

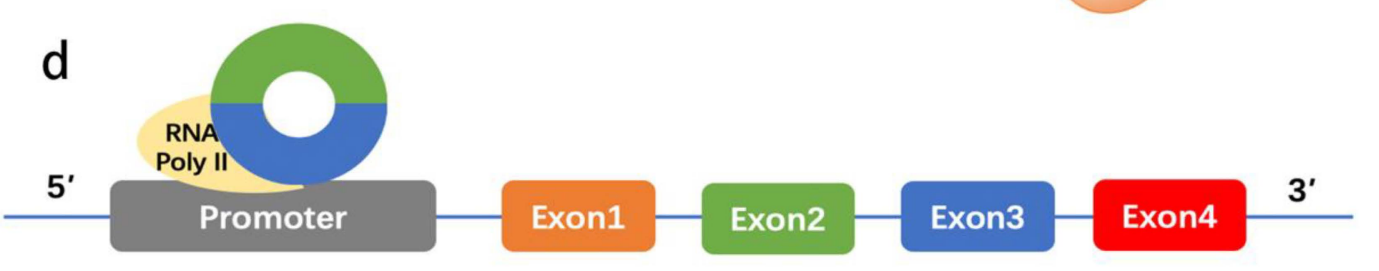

e

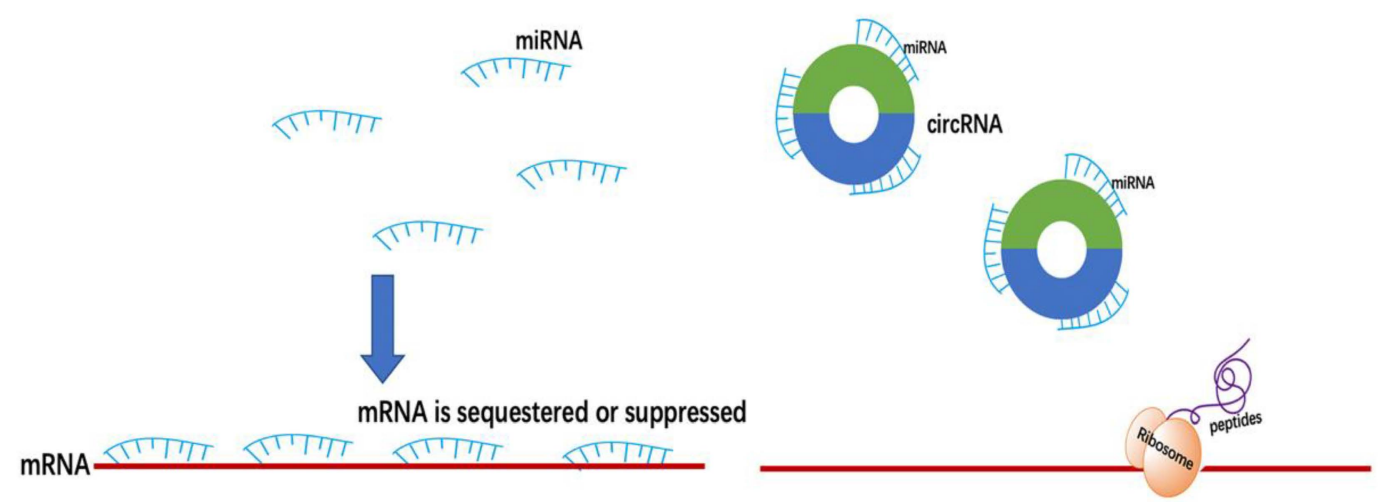

Figure 2. The main functions of circRNAs. (a) miRNA sponge; (b) protein sponge; (c) translating into peptides; (d) regulating the expression of the parental gene via interacting with RNA polymerase II and regulating transcription; (e) miRNA sponges alleviate the inhibitory effects of miRNAs on target mRNA.

Through novel bioinformatics approaches integrated with biochemical enrichment strategies and deep sequencing, circRNAs can be studied in a comprehensive and in-depth perspective $[30,31]$. Many online resources have been developed, such as identification tools, databases, detection software systems, websites, and recommended nomenclature of circRNAs [28,32-34]. Gene Ontology (GO) and the Kyoto Encyclopedia of Genes and Genomes (KEGG) pathway have generally been used to reveal the potential role of the differentially expressed circRNAs. As a rising star in the past few years, circRNAs have been proven to be involved in regulating liver homeostasis and diseases [35]. A certain number of circRNAs have been discovered as potential biomarkers or therapeutic targets 
for HCC [36-43]. As well as for HCC, circRNAs play an important role in non-neoplastic chronic liver diseases, such as ALD, MAFLD, liver fibrosis, and autoimmune diseases through epigenetic mechanisms [11,12,44-46].

Here, we conduct a literature review to summarize the role of circRNAs in ALD, MAFLD, viral hepatitis, liver injury and regeneration, liver cirrhosis, and autoimmune liver disease.

\section{Circular RNAs in Chronic Liver Diseases}

\subsection{Alcoholic Liver Disease (ALD)}

ALD, ranging from asymptomatic liver steatosis to alcoholic hepatitis and cirrhosis, is the most prevalent type of chronic liver disease worldwide [47]. ALD is characterized by fat accumulation, hepatocyte apoptosis, and inflammatory infiltration [48]. The pathogenesis of ALD involves several factors, including lipid deposition, excessive generation of reactive oxygen species (ROS), hepatocyte apoptosis, increased gut permeability, translocation of bacteria-derived lipopolysaccharides (LPS) from the gut into the liver, and excessive inflammatory responses that share some relationships with miRNAs and circRNAs $[47,49,50]$.

miR-122 is one of the most well-studied miRNAs. The target genes of miR-122 include genes that are related to lipid metabolism (HMGCG, ApoE, MTTP, and PGC1a), liver fibrosis (P4HA1), hepatocellular cancer-relevant genes (Igf1R, ADAM10, cyclin G1, and KLF6) [51], hypoxia-related genes (HIF1 $\alpha$ ) [52], and inflammatory responses-associated genes (TNFRSF13C) [49]. miR-122 is a suppressive factor in ALD, and is sponged by circRNA_1639. circRNA_1639 is a pro-inflammatory factor identified in primary Kupffer cells in $\mathrm{CCl}_{4}$-induced liver fibrosis. circRNA_1639 induces ALD via activating the NF- $\mathrm{KB}$ signaling pathway through circRNA_1639/miR-122/TNFRSF13C axis [49]. In other studies of alcohol-induced animal models, mm9_circ_018725 [53] and mou_circ_1657 [54] have contributed to ALD by releasing pro-inflammatory cytokines and activating HSCs via interacting with miR-96-5p, respectively. miR-21 also plays a protective role against ALD through the anti-extrinsic apoptotic signaling pathway [55], but no circRNA corresponding to it under the ceRNA mechanism has been reported yet.

Another pivotal miRNA, miR-155, is a crucial regulator for inflammation and is increased in the liver and circulation in ALD [47]. Kupffer cell activation and sensitization to LPS are regulated by miRNA-155 in ALD [51]. Bioinformatics analysis predicted that circRNA-0067835 acts as an miR-155 sponge to regulate FOXO3a expression in the progress of liver fibrosis [56]. However, there is no report in which circRNAs specifically interact with miR-155 in ALD.

In summary, ALD is caused by various factors, including genetics, epigenetics, and non-genetic factors. The ceRNA mechanism might also play an essential role in the development of ALD, an area which needs further study. Additionally, alcohol intake can lead to changes in the composition of the gut microbiota. Functional alterations in the microbiota have been proven to be associated with ALD progression [50]. Similarly, gut microbiota regulates tumor lung metastasis via a circRNA/miRNA network [57]. Accordingly, gut microbiota might also interact with the circRNA/miRNA network in ALD, making it a promising research direction.

\subsection{Metabolic-Associated Fatty Liver Disease (MAFLD)}

Nonalcoholic fatty liver disease (NAFLD) has become the most common cause of chronic liver diseases [58]. Nonalcoholic steatohepatitis (NASH), currently recognized as part of NAFLD, progresses into liver cirrhosis and further decompensation liver cirrhosis in some individuals [59]. Recently, international experts reached a consensus that the disease abbreviation should be changed from NAFLD to metabolic dysfunction-associated fatty liver disease (MAFLD) [60]. Insulin resistance and abnormal lipid metabolism [61] are the hallmarks of MAFLD, and many circRNAs have effects on oxidative stress, including mitochondrial dysfunction and endoplasmic reticulum (ER) stress [62], and on autophagy 
or lipophagy in fatty livers [63]. For example, LPIN1 is a crucial gene in regulating triglyceride and phospholipid biosynthesis [64]. The circRNA_021412/miR-1972/LPIN1 signaling pathway reflected the regulatory mechanisms underlying the steatosis-related circRNA-miRNA-mRNA network [65]. CircScd1 promotes fatty liver disease by increasing hepatocellular lipidosis in NAFLD via the JAK2/STAT5 pathway [66]. Low-density lipoprotein (LDL), peroxisome proliferator-activated receptor $\alpha($ PPAR $\alpha)$, and their corresponding genes are critical in lipometabolisim. circRNA_0049392 is differentially expressed in an NAFLD mouse model [67], whereas target miRNAs of circRNA_0049392 are miR-6919-5p and miR-7037-5p, which are validated to regulate LDL [67]. miR-34a, an inhibitor of PPAR $\alpha$, is significantly up-regulated in different models of rodent hepatic steatosis. circRNA_0046366 and circRNA_0046367, as the sponges of miR-34a, abolish the inhibitory effect of miR-34a on PPAR $\alpha$, thus ameliorating the lipoxidative stress [68,69]. The circRNA_002581/miR-122/CPEB1 axis promoting NASH is associated with the dysregulation of autophagy, which can be inhibited through the PTEN/AMPK/mTOR signaling pathway [70].

Liver fibrosis is also recognized as the hallmark of disease progression in NASH [58], and fibroblasts, along with HSCs, contribute to the occurrence and development of liver fibrosis. circRNA_29981, a potential regulator of HSC activation, was identified in the murine NASH model [71]. Moreover, a steatohepatitis-associated mitochondrial circRNASCAR can shut down the mitochondrial permeability transition pore (mPTP) by binding to ATP5B, thereby inhibiting mitochondrial ROS (mtROS) output and fibroblast activation [62]. It seems that circRNAs might also be involved in the progress of NASH to liver fibrosis. circRNAs are also involved in the efficacy and mechanism of NAFLD treatment. Metformin is now recommended for NAFLD treatment to improve insulin resistance in NAFLD [58]. Metformin systematically alleviates the transcriptome alterations induced by a high-fat diet, while the circRNA-miRNA-mRNA network may attribute to the beneficial effect of metformin on NAFLD [72]. The traditional Chinese medicine prescription, Qianggan formula, has also been reported to improve NASH by modulating the lncRNA/circRNA immune ceRNA network [73].

Altogether, there is increasing evidence suggesting that circRNAs, as well as ceRNA mechanisms, play a crucial role in the development and progression of MAFLD. It is a network where advances in the study of one molecule may provide ideas for the study of other disease mechanisms. For example, miR-34a also functions as a profibrotic factor that promotes alcohol-induced liver fibrosis by reducing HSC senescence and increasing the senescence of hepatocytes [74]. It is possible that in ALD, miR-34a could interact with certain circRNAs to promote or inhibit disease progression. Further studies are needed to deepen the mechanism.

\subsection{Viral Hepatitis (Hepatitis B and Hepatitis C)}

Chronic hepatitis B virus (HBV) infection is one of the leading causes of liver fibrosis, cirrhosis, and hepatocellular carcinoma [75,76]. Interferons (IFNs) are used in anti-HBV therapy. Recently, Zhang et al. found that the circRNA hsa_circ_0004812 could regulate the levels of IFNs and thus their anti-HBV efficiency [77]. Knockdown of hsa_circ_0004812 in HBV-infected cells resulted in a significant increase in mRNA and protein levels of IFN- $\alpha$ and IFN- $\beta$ [77]. TGF $\beta 2$ has suppressive effects on IL-2-dependent T-cell growth and is significantly down-regulated in chronic hepatitis B patients [78]. Zhou et al. found a strong positive correlation between hsa_circ_0000650 and TGF $\beta 2$ in the liver biopsies from chronic hepatitis $B$ patients compared with the control group, whereas a robust negative correlation between hsa_circ_0000650 and miR-6873-3p was also established [79].

Hepatitis $\mathrm{C}$ virus (HCV) is also an important pathogen of hepatitis, cirrhosis and HCC. HCV is hepatocyte-specific, partly due to its dependence on the host miR-122, which is exceptionally abundant in hepatocytes [80]. miR-122 is thought to enhance the viral RNA abundance and has already been utilized as a drug target for anti-HCV therapy [81]. Jost et al. designed artificial circRNAs containing an array of miR-122 binding sites, thus 
efficiently sequestering miR-122 [82]. They also found that these circRNAs might work as protein sponges containing binding sites derived from SELEX- or CLIP-data, and were available for multiple RNA-binding proteins [82]. Besides, circPSD3, inhibiting viral RNA abundance at a post-translational step, was shown to promote HCV infection [83].

As circRNAs are more stable than linear RNAs, they might play crucial roles in viral infection pathogenesis. Interestingly, there are also many covalently closed circular DNAs (cccDNA) in the genome of the hepatitis virus itself. For example, HBV cccDNA produced during HBV replication is predominant in the liver of $\mathrm{CHB}$ patients [84], and their levels can be regulated by the RNA-binding protein, DHX9 [85]. However, whether the circRNA originated from cccDNA remains unclear.

\subsection{Liver Injury and Liver Regeneration}

The liver has a remarkable capacity for regeneration when stimulated with physical (loss of volume or ischemia) or chemical (medicine or infection) damage [86]. In the $2 / 3$ partial hepatectomy $(\mathrm{PH})$ murine model, a ceRNA network containing 5 circRNAs, 28 target genes, and 533 miRNAs was identified during the DNA synthesis phase (36 h) of liver regeneration [87]. Knockdown of circ_0002498, circ_0000281, and circ_0003822 significantly restrained the proliferation of hepatocytes. In contrast, the knockdown of circ_0003745 and circ_0004245 accelerated the proliferation of hepatocytes [87]. Similarly, a circRNA-miRNA interactions network was also established in the rat $\mathrm{PH}$ model. Four significantly changed circRNAs (circ432, circ2077, circ1366, and circ15) were screened as key circRNAs during the priming phase of liver regeneration. These circRNAs might regulate the rat liver regeneration by controlling the expression of MAPK14, FN1, TNFRSF21, and GOT1, respectively [88].

Hepatic ischemia and reperfusion injury (IRI) are major complications during surgical procedures such as liver transplantation, liver resection, and trauma surgery [89]. The comprehensive analysis of circRNAs during hepatic IRI was performed using nextgeneration RNA sequencing [90,91], and several circRNAs were selected as potential targets against hepatic IRI. In the hepatic IRI model established by hepatic artery occlusion, circRNA_017753-miR-218-5p-Jade1, circRNA_017753-miR-7002-3p-Jade1, and circRNA_017753-miR-7008-3p-Jade1 ceRNA signaling pathways may play important roles in the mechanisms of ischemic preconditioning protection [92].

For the radiation-induced liver injury, circRSF1 was upregulated in irradiated LX2 cells, and promoted inflammatory and fibrotic phenotypes of HSC by sponging miR146a-5p [93]. Similarly, circTUBD1 acted as an miR-146a-5p sponge to affect the viability and pro-inflammatory cytokine production of LX-2 cells through the Toll-like receptor 4 (TLR4)/NF-kB signaling pathway [94]. These two studies suggest that circRSF1 and circTUBD1 are potential targets for radiation-induced liver disease therapy.

Drug-induced liver injury is one of the major causes of liver disease. For acetaminophen (APAP)-induced liver injury, p66Shc, a master regulator of $\mathrm{mtROS}$, is upregulated in liver tissues in response to APAP. circ-CBFB acts as the sponge of miR-185-5p, triggering mitochondrial dynamics perturbation via p66Shc [95]. For the hydrogen peroxide $\left(\mathrm{H}_{2} \mathrm{O}_{2}\right)-$ induced injury, circRNA-4099 augments $\mathrm{H}_{2} \mathrm{O}_{2}$-induced damage by inhibiting miR-706 and triggering Keap1/Nrf2 and p38MAPK in the L02 cells [96]. For anti-tuberculosis druginduced liver injury, circMARS may participate in the compensation and regeneration of the liver through the circMARS-miR-6808-5p/miR-6874-3p/miR-3157-5p-KMT2C-EGFR functional axis [97].

For infection-induced liver injury, the mmu_circRNA_005186/miR-124-3p/Epha2 axis is associated with LPS-induced inflammation, and silencing mmu_circRNA_005186 attenuates this kind of inflammation [98]; circ_0003420 also mediates LPS-induced cellular injury and inflammation, mainly by targeting the neuronal PAS domain protein 4 (NPAS4) mRNA [99]. 
The current knowledge mentioned above is somewhat about the critical role of circRNAs in liver injury and liver regeneration. However, further studies that deepen the underlying mechanisms in these liver injuries are still urgently needed.

\subsection{Liver Fibrosis/Cirrhosis}

During chronic liver diseases, persistent inflammatory responses and parenchymal injury eventually lead to liver fibrosis and liver cirrhosis [100,101]. Chronic loss of hepatocytes occurs in chronic liver diseases of any etiology and is associated with the activation of HSCs and an abnormal liver microenvironment [6]. Thus, inhibiting HSC activation has been considered as one of the most potent approaches to alleviate the progression of liver cirrhosis.

Many circRNAs have been found to suppress the activation of HSCs. Telomeraseassociated protein 1 (TEP1), a component of telomerase and target of hsa-miR-660-3p [102], plays a key role in the development of liver fibrosis and cirrhosis [103]. Overexpression of hsa_circ_0004018, a sponge of hsa-miR-660-3p, increases the expression of TEP1 and significantly suppresses the proliferation and activation of HSCs [104]. Consistently, hsa_circ_0007874 (cMTO1) could inhibit HSC activation through sponging miR-181b-5p and miR-17-5p [105,106]. Besides, hsa_circ_0070963 inhibits liver fibrosis via the regulation of miR-223-3p, which is related to HSC activation [107]. By targeting miR-18b-3p, circFBXW4 attenuates murine liver fibrogenesis with an anti-inflammation effect via inhibiting the activation and proliferation of HSCs, and inducing HSC apoptosis [108]. Moreover, mmu_circ_34116 can also inhibit the HSC activation via mmu_circ_34116/miR22-3P / BMP7 signal axis $[109,110]$. Recently, circPSD3 was found to inhibit the activation and proliferation of HSCs by targeting the miR-92b-3p/Smad7 axis [111].

As mentioned above, these circRNAs keep HSCs in quiescent status. However, there are still some circRNAs that promote the activation of HSCs through different mechanisms. Follistatin-like 1 (Fstl1) contributes to TGF- $\beta$-induced HSC proliferation, the expression of $\alpha$-SMA, and type I collagen, while TLR4 contributes to LPS-induced HSC activation [112]. circ-PWWP2A sponges miR-203 and miR-223, and subsequently increases the expression of Fstl1 and TLR4, respectively, eventually promoting the activation and proliferation of HSCs [112,113]. circRNA-0067835 acts as a sponge of miR-155 to promote FOXO3a expression, subsequently promoting fibrosis progression [56]. hsa_circ_0071410 decreases the expression of miR-9-5p, resulting in the progression of irradiation-induced HSC activation $[114,115]$.

IncRNAs have also been shown to regulate the process of liver fibrosis by inhibiting miRNAs. For example, lncRNA-p21 can inhibit miR-181b and miR-17-5p, which in turn inhibit the activation of HSCs through two different signaling pathways [20]. Interestingly, both cMTO1 and lncRNA-p21 sponge miR-181b and miR-17-5p, which indicates the potential circRNA-miRNA-lncRNA network in the development of liver fibrosis.

Liver cirrhosis is a common ultimate consequence of chronic liver diseases. As HSCs are supposed to be a major source of collagen deposit during liver cirrhosis, the role of circRNAs in HSC activation attracts the most attention during chronic liver diseases. The hepatic cells are mainly composed of hepatocytes, LSECs, HSCs, cholangiocytes, and Kupffer cells, which precisely "cross-talk" to maintain normal hepatic functions and to aid cell survival [116]. Thus, the functions of circRNAs from other hepatic cells should also be investigated during chronic liver diseases and liver cirrhosis.

\subsection{Autoimmune Liver Disease}

Currently, the most common autoimmune liver diseases in clinical practice are primary biliary cholangitis (PBC), primary sclerosing cholangitis (PSC), and autoimmune hepatitis (AIH) [117]. They have a high heterogeneity of clinical presentation and result from the interactions of multiple genetic and environmental factors. circRNAs can contribute to the development of autoimmune diseases, mainly by serving as miRNA sponges to regulate DNA methylation, immune response and inflammatory response [118]. miR-522-3p might 
be involved in chronic inflammatory disorders, and miR-943 is a participant in the repair of DNA double-strand breaks [119]. Zheng et al. found that hsa_circ_402458, the sponge of hsa-miR-522-3p and hsa-miR-943, was significantly higher in PBC patients not treated with ursodeoxycholic acid (UDCA) than in those treated with it [119]. Liu et al. recently reported that the pathogenesis of AIH may involve the mmu_circ_0001520/mmu-miR-193b3p/MAPK10 axis [120]. However, the role of circRNAs in PSC has not yet been reported. Overall, there are relatively few studies focusing on circRNAs and autoimmune liver disease. The etiology of autoimmune diseases is complex [121]. In different diseases, there is a significant overlap of susceptibility factors. Thus, the role of circRNAs in autoimmune liver disease may be complicated and would benefit from further study.

\section{Conclusions and Prospects}

In this literature review, we discussed the epigenetic role of circRNAs in non-neoplastic chronic liver diseases (Table 1). Almost all current studies suggest that circRNAs act in chronic liver diseases through the ceRNA mechanism, i.e., through interactions with miRNAs, supporting a certain association between circRNAs and chronic liver diseases (Figure 3). Some miRNAs can interact with both circRNAs and lncRNAs in hepatic fibrosis, but in other chronic liver diseases, such intermediate miRNAs have not been reported.

ALD
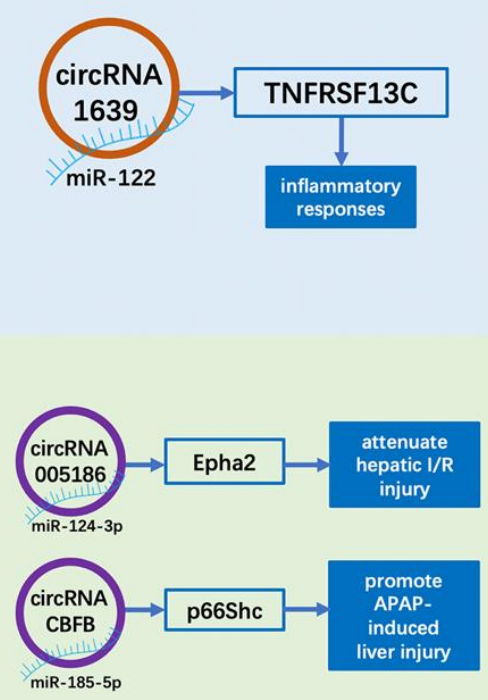

Liver Injury
Liver fibrosis/Cirrhosis
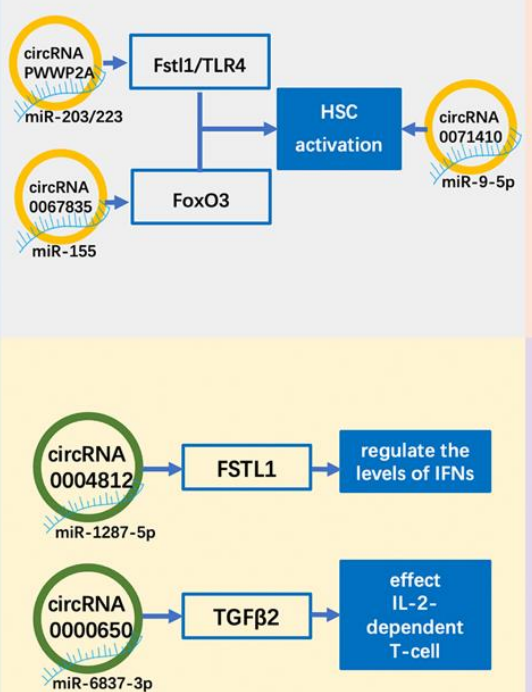

Hepatitis B
AlH
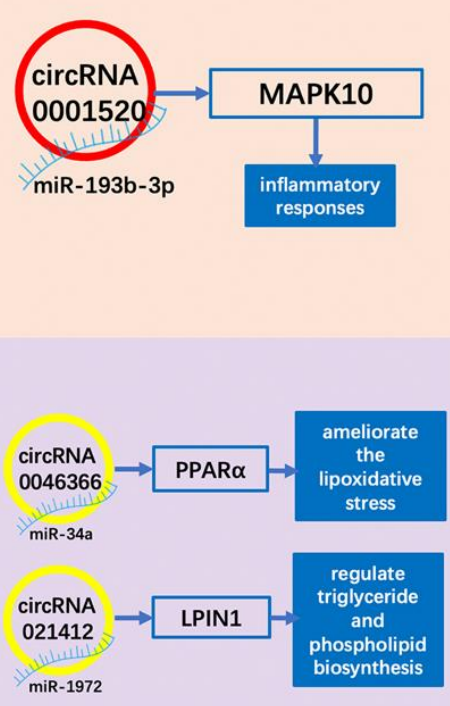

MAFLD

Figure 3. Examples of circRNAs in chronic liver diseases. ALD: alcoholic liver disease; MAFLD: metabolicassociated fatty liver disease; AIH: autoimmune hepatitis; HSC: hepatic stellate cell; I/R: ischemia/reperfusion; APAP: acetaminophen; IFN: interferon. 
However, the ceRNA network is more than just the interaction of circRNAs and miRNAs. Expressed $3^{\prime}$ untranslated regions ( $3^{\prime}$ UTRs), pseudogenes and lncRNAs may also act as ceRNAs to sequester miRNA activity by competing for miRNA binding sites. Investigating further connections among circRNA, miRNA and lncRNA in liver diseases could be a promising research direction in the future. Besides, circRNAs can be obtained from tissues, serum, and exosomes. The expression and function of circRNAs in the sites mentioned above may vary due to the different microenvironments. The clearance of circRNAs can be seen under a possible mechanism that is eliminating circRNAs from cells into the extracellular space by extracellular vesicles [24,25]. However, there are few studies on the role and function of circRNAs in serum and exosomes. Research on large samples from different sources is warranted to understand these circRNAs further.

Another important part of epigenetics is $\mathrm{m}^{6} \mathrm{~A}$ modification. $\mathrm{m}^{6} \mathrm{~A}$ modification plays a unique role in critical physiological hepatic functions and various liver diseases. It participates in glucose and lipid homeostasis involving the development of MAFLD and liver cancer pathogenesis and metastasis $[122,123] . \mathrm{m}^{6} \mathrm{~A}$ is the most abundant internal modification known on DNA, mRNAs and lncRNAs [124,125]. Almost all studies have focused on the effects of $\mathrm{m}^{6} \mathrm{~A}$ and mRNA, miRNA or IncRNA in MAFLD, liver fibrosis, PBC, and HCC [45,123,126-129]. $\mathrm{m}^{6} \mathrm{~A}$ is widespread in circRNAs [130], regulating circRNA translation and facilitating circRNA degradation [131]. However, the relationship between $\mathrm{m}^{6} \mathrm{~A}$ and circRNAs in chronic liver diseases remains unclear. Recently, Zhou et al. defined thousands of $\mathrm{m}^{6} \mathrm{~A}$ circRNAs with cell-type-specific expression [130]. Although much of the same cellular machinery is shared between $\mathrm{m}^{6} \mathrm{~A}$-modified circRNAs and mRNAs, $\mathrm{m}^{6} \mathrm{~A}$ circRNAs exhibit distinct patterns of $\mathrm{m}^{6} \mathrm{~A}$ modifications compared with mRNAs. The discovery of $\mathrm{m}^{6} \mathrm{~A}$ circRNAs raises many questions that will need to be addressed in future studies.

Liver diseases are a heavy burden on healthcare and account for significant costs worldwide. Clinicians and public health professionals may be more interested in how to use the characteristics of circRNAs and their interconnections with other molecules to diagnose and treat liver diseases. The articles published so far only provide new theories or ideas from the perspective of basic research, and there is still a long way to go before any clinical application. Therefore, it is worthwhile to reveal the full biological relevance of circRNAs and their potential therapeutics.

In conclusion, circRNAs play an increasingly crucial role in the epigenetic regulation of the onset and progression of chronic liver diseases. Further efforts are urgently needed in order to develop circRNAs as novel diagnostics and therapeutics. 
Table 1. Summary of circRNAs involved in chronic liver diseases.

\begin{tabular}{|c|c|c|c|c|}
\hline Diseases & CircRNA or LncRNA & Possible Mechanisms & Expression Change & Refs. \\
\hline \multirow[t]{3}{*}{ ALD } & circRNA_1639 & $\begin{array}{l}\text { circ_1639/miR-122/TNFRSF13C axis and NF-kB } \\
\text { pathway }\end{array}$ & up-regulation & [49] \\
\hline & mou_circ_1657 & sponge miR-96-5p & up-regulation & [54] \\
\hline & $\operatorname{circScd} 1$ & JAK2/STAT5 pathway & down-regulation & [66] \\
\hline \multirow{5}{*}{ MAFLD } & circRNA_0049392 & target miR-7037-5p and miR-6919-5p & up-regulation & [67] \\
\hline & circRNA_0046366, circRNA_0046367 & circRNA_0046366,7/miR-34a/PPAR $\alpha$ axis & down-regulation & {$[68,69]$} \\
\hline & circRNA_021412 & circRNA_021412/miR-1972/LPIN1 axis & down-regulation & [65] \\
\hline & circRNA SCAR & shut down mPTP by binding to ATP5B & down-regulation & [62] \\
\hline & hsa_circ_0004812 & circ_0004812/miR-1287-5p/FSTL1 axis & up-regulation & [77] \\
\hline \multirow[t]{3}{*}{ Viral hepatitis } & hsa_circ_0000650 & hsa_circ_0000650/miR-6873-3p and TGF $\beta 2$ axis & down-regulation & [79] \\
\hline & circPSD3 & $\begin{array}{l}\text { bind factor eIF4A3; nonsense-mediated decay } \\
\text { (NMD) pathway }\end{array}$ & up-regulation & [83] \\
\hline & circ432, $\operatorname{circ} 2077, \operatorname{circ} 1366$ and $\operatorname{circ} 15$ & $\begin{array}{c}\text { controlling the expression level of MAPK14, FN1, } \\
\text { TNFRSF21 and GOT1 }\end{array}$ & up-regulation & [88] \\
\hline \multirow{9}{*}{$\begin{array}{l}\text { Liver injury } \\
\quad \text { and } \\
\text { regeneration }\end{array}$} & circRNA_017753 & $\begin{array}{c}\text { circRNA_017753/miR-218-5p, miR-7002-3p, } \\
\text { miR-7008-3p/Jade1 }\end{array}$ & up-regulation & [92] \\
\hline & circRSF1 & $\begin{array}{l}\text { promoting inflammatory and fibrotic phenotypes } \\
\text { of HSC by sponging miR-146a-5p }\end{array}$ & up-regulation & [93] \\
\hline & circTUBD1 & $\begin{array}{l}\text { circTUBD1/miR-146a-5p/Toll-like receptor } \\
\text { 4/NF- } \mathrm{kB} \text { axis }\end{array}$ & up-regulation & [94] \\
\hline & circ-CBFB & circ-CBFB/miR-185-5p/p66Shc axis & up-regulation & [95] \\
\hline & circRNA-4099 & $\begin{array}{c}\text { circRNA-4099/miR-706/keap1/Nrf2 and } \\
\text { p38MAPK axis }\end{array}$ & down-regulation & {$[96]$} \\
\hline & circMARS & $\begin{array}{c}\text { circMARS-miR-6808-5p/-6874-3p/-3157-5p- } \\
\text { KMT2C-EGFR functional } \\
\text { axis }\end{array}$ & up-regulation & [97] \\
\hline & mmu_circRNA_005186 & mmu_circRNA_005186/miR-124-3p/Epha2 axis & up-regulation & [98] \\
\hline & hsa_circ_0004018 & $\begin{array}{c}\text { hsa_circ_0004018/hsa-miR-660-3p/TEP1 axis; } \\
\text { inhibits liver fibrosis }\end{array}$ & down-regulation & {$[104]$} \\
\hline & hsa_circ_0007874 (cMTO1) & $\begin{array}{c}\text { inhibit HSC activation through sponging } \\
\text { miR-181b-5p and miR-17-5p }\end{array}$ & down-regulation & $\begin{array}{l}{[105,} \\
106]\end{array}$ \\
\hline \multirow[t]{7}{*}{$\begin{array}{l}\text { Liver fibro- } \\
\text { sis/Cirrhosis }\end{array}$} & hsa_circ_0070963 & $\begin{array}{l}\text { inhibits liver fibrosis via regulation of miR-223-3p } \\
\text { that related to HSC activation }\end{array}$ & down-regulation & {$[107]$} \\
\hline & circFBXW4 & $\begin{array}{l}\text { circFBXW4/miR-18b-3p/FBXW7 axis; inhibit } \\
\text { fibrosis }\end{array}$ & down-regulation & {$[108]$} \\
\hline & mmu_circ_34116 & $\begin{array}{c}\text { mmu_circ_34116/miR-22-3P/BMP7 signal axis; } \\
\text { inhibit HSC activation }\end{array}$ & down-regulation & $\begin{array}{l}{[109,} \\
110]\end{array}$ \\
\hline & circPSD3 & $\operatorname{circPSD} 3 / \mathrm{miR}-92 \mathrm{~b}-3 \mathrm{p} / \mathrm{Smad} 7$ & down-regulation & [111] \\
\hline & circ-PWWP2A & $\begin{array}{l}\text { circ-PWWP2A/miR-203 and miR-223/Fstl } 1 \text { and } \\
\text { TLR4 axis; promote HSC activation }\end{array}$ & up-regulation & [112, \\
\hline & circRNA-0067835 & $\begin{array}{c}\text { circRNA-0067835/miR-155/FoxO3 axis; promote } \\
\text { HSC activation }\end{array}$ & up-regulation & [56] \\
\hline & hsa_circ_0071410 & $\begin{array}{c}\text { sponge miR-9-5p; promote irradiation-induced } \\
\text { HSC activation }\end{array}$ & up-regulation & $\begin{array}{l}{[114,} \\
115]\end{array}$ \\
\hline \multirow{2}{*}{$\begin{array}{l}\text { Autoimmune } \\
\text { liver disease }\end{array}$} & hsa_circ_402458 & sponge hsa-miR-522-3p and hsa-miR-943 & up-regulation & [119] \\
\hline & mmu_circ_0001520 & $\begin{array}{l}\text { mmu_circ_0001520/mmu-miR-193b- } \\
\text { 3p/MAPK10 }\end{array}$ & up-regulation & {$[120]$} \\
\hline
\end{tabular}

Author Contributions: J.G. conceived and supervised the study; X.Z., X.Y., Q.C. and C.T. analyzed articles and finalized the figures; X.Z., C.T. and J.G. wrote the manuscript with input from all the authors. All authors have read and agreed to the published version of the manuscript.

Funding: This research was funded by the Natural Science Fund of China (81670551, U1702281, 81873584, 82000613 and 82000574); Sichuan Science and Technology Program (2020YJ0084 and 2021YFS0147); National Key R\&D Program of China (2017YFA0205404).

Conflicts of Interest: The authors declare no conflict of interest.

\section{References}

1. Kubes, P.; Jenne, C. Immune Responses in the Liver. Annu. Rev. Immunol. 2018, 36, 247-277. [CrossRef]

2. Trefts, E.; Gannon, M.; Wasserman, D.H. The liver. Curr. Biol. 2017, 27, R1147-R1151. [CrossRef]

3. Sato, K.; Kennedy, L.; Liangpunsakul, S.; Kusumanchi, P.; Yang, Z.; Meng, F.; Glaser, S.; Francis, H.; Alpini, G. Intercellular Communication between Hepatic Cells in Liver Diseases. Int. J. Mol. Sci. 2019, 20, 2180. [CrossRef]

4. Jarido, V.; Kennedy, L.; Hargrove, L.; Demieville, J.; Thomson, J.; Stephenson, K.; Francis, H. The emerging role of mast cells in liver disease. Am. J. Physiol. Gastrointest. Liver Physiol. 2017, 313, G89-G101. [CrossRef] [PubMed] 
5. Francis, H.; Meininger, C.J. A review of mast cells and liver disease: What have we learned? Dig. Liver Dis. 2010, 42, 529-536. [CrossRef] [PubMed]

6. Michalopoulos, G.K.; Bhushan, B. Liver regeneration: Biological and pathological mechanisms and implications. Nat. Rev. Gastroenterol. Hepatol. 2021, 18, 40-55. [CrossRef] [PubMed]

7. Duncan, A.W.; Dorrell, C.; Grompe, M. Stem cells and liver regeneration. Gastroenterology 2009, 137, 466-481. [CrossRef] [PubMed]

8. Asrani, S.K.; Devarbhavi, H.; Eaton, J.; Kamath, P.S. Burden of liver diseases in the world. J. Hepatol. 2019, 70, 151-171. [CrossRef] [PubMed]

9. Wang, F.S.; Fan, J.G.; Zhang, Z.; Gao, B.; Wang, H.Y. The global burden of liver disease: The major impact of China. Hepatology 2014, 60, 2099-2108. [CrossRef]

10. Mokdad, A.A.; Lopez, A.D.; Shahraz, S.; Lozano, R.; Mokdad, A.H.; Stanaway, J.; Murray, C.J.; Naghavi, M. Liver cirrhosis mortality in 187 countries between 1980 and 2010: A systematic analysis. BMC Med. 2014, 12, 145. [CrossRef]

11. Hardy, T.; Mann, D.A. Epigenetics in liver disease: From biology to therapeutics. Gut 2016, 65, 1895-1905. [CrossRef] [PubMed]

12. Mann, D.A. Epigenetics in liver disease. Hepatology 2014, 60, 1418-1425. [CrossRef]

13. Blum, H.E. Gastrointestinal and liver diseases: Genetic and epigenetic markers. Gut 2011, 60, 1630-1634. [CrossRef]

14. Zhang, L.; Lu, Q.; Chang, C. Epigenetics in Health and Disease. Adv. Exp. Med. Biol. 2020, 1253, 3-55. [CrossRef]

15. Cavalli, G.; Heard, E. Advances in epigenetics link genetics to the environment and disease. Nature 2019, 571, 489-499. [CrossRef]

16. Thomson, D.W.; Dinger, M.E. Endogenous microRNA sponges: Evidence and controversy. Nat. Rev. Genet. 2016, 17, $272-283$. [CrossRef] [PubMed]

17. Lai, S.; Iwakiri, Y. Is miR-21 a potent target for liver fibrosis? Hepatology 2018, 67, 2082-2084. [CrossRef]

18. Mercer, T.R.; Dinger, M.E.; Mattick, J.S. Long non-coding RNAs: Insights into functions. Nat. Rev. Genet. 2009, 10, 155-159. [CrossRef] [PubMed]

19. Shabgah, A.G.; Norouzi, F.; Hedayati-Moghadam, M.; Soleimani, D.; Pahlavani, N.; Navashenaq, J.G. A comprehensive review of long non-coding RNAs in the pathogenesis and development of non-alcoholic fatty liver disease. Nutr. Metab. 2021, 18, 22. [CrossRef] [PubMed]

20. Peng, H.; Wan, L.Y.; Liang, J.J.; Zhang, Y.Q.; Ai, W.B.; Wu, J.F. The roles of lncRNA in hepatic fibrosis. Cell Biosci. $2018,8,63$. [CrossRef] [PubMed]

21. Takahashi, K.; Yan, I.; Haga, H.; Patel, T. Long noncoding RNA in liver diseases. Hepatology 2014, 60, 744-753. [CrossRef]

22. Wang, Y.; Hylemon, P.B.; Zhou, H. Long non-coding RNA H19: A key player in liver diseases. Hepatology 2021. [CrossRef] [PubMed]

23. Patop, I.L.; Wüst, S.; Kadener, S. Past, present, and future of circRNAs. Embo. J. 2019, 38, e100836. [CrossRef] [PubMed]

24. Yao, T.; Chen, Q.; Fu, L.; Guo, J. Circular RNAs: Biogenesis, properties, roles, and their relationships with liver diseases. Hepatol. Res. 2017, 47, 497-504. [CrossRef]

25. Lasda, E.; Parker, R. Circular RNAs Co-Precipitate with Extracellular Vesicles: A Possible Mechanism for circRNA Clearance. PLoS ONE 2016, 11, e0148407. [CrossRef]

26. Park, O.H.; Ha, H.; Lee, Y.; Boo, S.H.; Kwon, D.H.; Song, H.K.; Kim, Y.K. Endoribonucleolytic Cleavage of m(6)A-Containing RNAs by RNase P/MRP Complex. Mol. Cell 2019, 74, 494-507.e498. [CrossRef] [PubMed]

27. Hansen, T.B.; Jensen, T.I.; Clausen, B.H.; Bramsen, J.B.; Finsen, B.; Damgaard, C.K.; Kjems, J. Natural RNA circles function as efficient microRNA sponges. Nature 2013, 495, 384-388. [CrossRef] [PubMed]

28. Haque, S.; Harries, L.W. Circular RNAs (circRNAs) in Health and Disease. Genes 2017, 8, 353. [CrossRef] [PubMed]

29. Fu, L.Y.; Wang, S.W.; Hu, M.Y.; Jiang, Z.L.; Shen, L.L.; Zhou, Y.P.; Guo, J.M.; Hu, Y.R. Circular RNAs in liver diseases: Mechanisms and therapeutic targets. Life Sci. 2021, 264, 118707. [CrossRef] [PubMed]

30. Hansen, T.B.; Venø, M.T.; Damgaard, C.K.; Kjems, J. Comparison of circular RNA prediction tools. Nucleic Acids Res. 2016, 44, e58. [CrossRef] [PubMed]

31. Jeck, W.R.; Sharpless, N.E. Detecting and characterizing circular RNAs. Nat. Biotechnol. 2014, 32, 453-461. [CrossRef] [PubMed]

32. Liu, M.; Wang, Q.; Shen, J.; Yang, B.B.; Ding, X. Circbank: A comprehensive database for circRNA with standard nomenclature. RNA Biol. 2019, 16, 899-905. [CrossRef]

33. Glažar, P.; Papavasileiou, P.; Rajewsky, N. circBase: A database for circular RNAs. RNA 2014, 20, 1666-1670. [CrossRef]

34. Wang, J.; Samuels, D.C.; Zhao, S.; Xiang, Y.; Zhao, Y.Y.; Guo, Y. Current Research on Non-Coding Ribonucleic Acid (RNA). Genes 2017, 8, 366. [CrossRef]

35. Song, M.; Xia, L.; Sun, M.; Yang, C.; Wang, F. Circular RNA in Liver: Health and Diseases. Adv. Exp. Med. Biol. 2018, 1087, 245-257. [CrossRef] [PubMed]

36. Wen, J.; Liao, J.; Liang, J.; Chen, X.P.; Zhang, B.; Chu, L. Circular RNA HIPK3: A Key Circular RNA in a Variety of Human Cancers. Front. Oncol. 2020, 10, 773. [CrossRef]

37. Li, D.; Zhang, J.; Li, J. Role of miRNA sponges in hepatocellular carcinoma. Clin. Chim. Acta 2020, 500, 10-19. [CrossRef]

38. Shang, W.; Adzika, G.K.; Li, Y.; Huang, Q.; Ding, N.; Chinembiri, B.; Rashid, M.S.; Machuki, J.O. Molecular mechanisms of circular RNAs, transforming growth factor- $\beta$, and long noncoding RNAs in hepatocellular carcinoma. Cancer Med. 2019, 8, 6684-6699. [CrossRef] [PubMed]

39. Qiu, L.; Xu, H.; Ji, M.; Shang, D.; Lu, Z.; Wu, Y.; Tu, Z.; Liu, H. Circular RNAs in hepatocellular carcinoma: Biomarkers, functions and mechanisms. Life Sci. 2019, 231, 116660. [CrossRef] 
40. Wang, M.; Yu, F.; Li, P. Circular RNAs: Characteristics, Function and Clinical Significance in Hepatocellular Carcinoma. Cancers 2018, 10, 258. [CrossRef]

41. Qiu, L.P.; Wu, Y.H.; Yu, X.F.; Tang, Q.; Chen, L.; Chen, K.P. The Emerging Role of Circular RNAs in Hepatocellular Carcinoma. J. Cancer 2018, 9, 1548-1559. [CrossRef] [PubMed]

42. Hu, J.; Li, P.; Song, Y.; Ge, Y.X.; Meng, X.M.; Huang, C.; Li, J.; Xu, T. Progress and prospects of circular RNAs in Hepatocellular carcinoma: Novel insights into their function. J. Cell Physiol. 2018, 233, 4408-4422. [CrossRef] [PubMed]

43. Fu, L.; Jiang, Z.; Li, T.; Hu, Y.; Guo, J. Circular RNAs in hepatocellular carcinoma: Functions and implications. Cancer Med. 2018, 7,3101-3109. [CrossRef]

44. Tanaka, A.; Leung, P.S.C.; Gershwin, M.E. The genetics of primary biliary cholangitis. Curr. Opin Gastroenterol. 2019, 35, 93-98. [CrossRef]

45. Eslam, M.; Valenti, L.; Romeo, S. Genetics and epigenetics of NAFLD and NASH: Clinical impact. J. Hepatol. 2018, 68, 268-279. [CrossRef]

46. Chien, Y.; Tsai, P.H.; Lai, Y.H.; Lu, K.H.; Liu, C.Y.; Lin, H.F.; Huang, C.S.; Wu, W.W.; Wang, C.Y. CircularRNA as novel biomarkers in liver diseases. J. Chin. Med. Assoc. 2020, 83, 15-17. [CrossRef] [PubMed]

47. Seitz, H.K.; Bataller, R.; Cortez-Pinto, H.; Gao, B.; Gual, A.; Lackner, C.; Mathurin, P.; Mueller, S.; Szabo, G.; Tsukamoto, H. Alcoholic liver disease. Nat. Rev. Dis. Primers 2018, 4, 16. [CrossRef] [PubMed]

48. Sehrawat, T.S.; Liu, M.; Shah, V.H. The knowns and unknowns of treatment for alcoholic hepatitis. Lancet Gastroenterol. Hepatol. 2020, 5, 494-506. [CrossRef]

49. Lu, X.; Liu, Y.; Xuan, W.; Ye, J.; Yao, H.; Huang, C.; Li, J. Circ_1639 induces cells inflammation responses by sponging miR-122 and regulating TNFRSF13C expression in alcoholic liver disease. Toxicol. Lett. 2019, 314, 89-97. [CrossRef]

50. Bajaj, J.S. Alcohol, liver disease and the gut microbiota. Nat. Rev. Gastroenterol. Hepatol. 2019, 16, 235-246. [CrossRef]

51. Szabo, G.; Satishchandran, A. MicroRNAs in alcoholic liver disease. Semin. Liver Dis. 2015, 35, 36-42. [CrossRef]

52. Satishchandran, A.; Ambade, A.; Rao, S.; Hsueh, Y.C.; Iracheta-Vellve, A.; Tornai, D.; Lowe, P.; Gyongyosi, B.; Li, J.; Catalano, D.; et al. MicroRNA 122, Regulated by GRLH2, Protects Livers of Mice and Patients From Ethanol-Induced Liver Disease. Gastroenterology 2018, 154, 238-252.e237. [CrossRef]

53. Meng, H.; Wang, L.; You, H.; Huang, C.; Li, J. Circular RNA expression profile of liver tissues in an EtOH-induced mouse model of alcoholic hepatitis. Eur. J. Pharmacol. 2019, 862, 172642. [CrossRef] [PubMed]

54. Dou, X.; Feng, L.; Ying, N.; Ding, Q.; Song, Q.; Jiang, F.; Wang, C.; Li, S. RNA Sequencing Reveals a Comprehensive Circular RNA Expression Profile in a Mouse Model of Alcoholic Liver Disease. Alcohol. Clin. Exp. Res. 2020, 44, 415-422. [CrossRef]

55. Francis, H.; McDaniel, K.; Han, Y.; Liu, X.; Kennedy, L.; Yang, F.; McCarra, J.; Zhou, T.; Glaser, S.; Venter, J.; et al. Regulation of the extrinsic apoptotic pathway by microRNA-21 in alcoholic liver injury. J. Biol. Chem. 2014, 289, 27526-27539. [CrossRef]

56. Zhu, L.; Ren, T.; Zhu, Z.; Cheng, M.; Mou, Q.; Mu, M.; Liu, Y.; Yao, Y.; Cheng, Y.; Zhang, B.; et al. Thymosin- $\beta 4$ Mediates Hepatic Stellate Cell Activation by Interfering with CircRNA-0067835/miR-155/FoxO3 Signaling Pathway. Cell Physiol. Biochem. 2018, 51, 1389-1398. [CrossRef] [PubMed]

57. Zhu, Z.; Huang, J.; Li, X.; Xing, J.; Chen, Q.; Liu, R.; Hua, F.; Qiu, Z.; Song, Y.; Bai, C.; et al. Gut microbiota regulate tumor metastasis via circRNA/miRNA networks. Gut Microbes 2020, 12, 1788891. [CrossRef] [PubMed]

58. Sanyal, A.J. Past, present and future perspectives in nonalcoholic fatty liver disease. Nat. Rev. Gastroenterol. Hepatol. 2019, 16, 377-386. [CrossRef]

59. Neuschwander-Tetri, B.A. Non-alcoholic fatty liver disease. BMC Med. 2017, 15, 45. [CrossRef]

60. Eslam, M.; Newsome, P.N.; Sarin, S.K.; Anstee, Q.M.; Targher, G.; Romero-Gomez, M.; Zelber-Sagi, S.; Wai-Sun Wong, V.; Dufour, J.F.; Schattenberg, J.M.; et al. A new definition for metabolic dysfunction-associated fatty liver disease: An international expert consensus statement. J. Hepatol. 2020, 73, 202-209. [CrossRef]

61. Yu, G.; Yang, Z.; Peng, T.; Lv, Y. Circular RNAs: Rising stars in lipid metabolism and lipid disorders. J. Cell Physiol. 2021, 236, 4797-4806. [CrossRef]

62. Zhao, Q.; Liu, J.; Deng, H.; Ma, R.; Liao, J.Y.; Liang, H.; Hu, J.; Li, J.; Guo, Z.; Cai, J.; et al. Targeting Mitochondria-Located circRNA SCAR Alleviates NASH via Reducing mROS Output. Cell 2020, 183, 76-93. [CrossRef]

63. Chen, C.; Zhang, X.; Deng, Y.; Cui, Q.; Zhu, J.; Ren, H.; Liu, Y.; Hu, X.; Zuo, J.; Peng, Y. Regulatory roles of circRNAs in adipogenesis and lipid metabolism: Emerging insights into lipid-related diseases. FEBS J. 2020. [CrossRef] [PubMed]

64. Csaki, L.S.; Reue, K. Lipins: Multifunctional lipid metabolism proteins. Annu. Rev. Nutr. 2010, 30, 257-272. [CrossRef] [PubMed]

65. Guo, X.Y.; He, C.X.; Wang, Y.Q.; Sun, C.; Li, G.M.; Su, Q.; Pan, Q.; Fan, J.G. Circular RNA Profiling and Bioinformatic Modeling Identify Its Regulatory Role in Hepatic Steatosis. Biomed. Res. Int. 2017, 2017, 5936171. [CrossRef] [PubMed]

66. Li, P.; Shan, K.; Liu, Y.; Zhang, Y.; Xu, L.; Xu, L. CircScd1 Promotes Fatty Liver Disease via the Janus Kinase 2/Signal Transducer and Activator of Transcription 5 Pathway. Dig. Dis. Sci. 2019, 64, 113-122. [CrossRef]

67. Yuan, X.; Diao, J.; Du, A.; Wen, S.; Zhou, L.; Pan, Y. Circular RNA expression profiles and features in NAFLD mice: A study using RNA-seq data. J. Transl. Med. 2020, 18, 476. [CrossRef]

68. Guo, X.Y.; Sun, F.; Chen, J.N.; Wang, Y.Q.; Pan, Q.; Fan, J.G. circRNA_0046366 inhibits hepatocellular steatosis by normalization of PPAR signaling. World J. Gastroenterol. 2018, 24, 323-337. [CrossRef]

69. Guo, X.Y.; Chen, J.N.; Sun, F.; Wang, Y.Q.; Pan, Q.; Fan, J.G. circRNA_0046367 Prevents Hepatoxicity of Lipid Peroxidation: An Inhibitory Role against Hepatic Steatosis. Oxid Med. Cell Longev. 2017, 2017, 3960197. [CrossRef] 
70. Jin, X.; Gao, J.; Zheng, R.; Yu, M.; Ren, Y.; Yan, T.; Huang, Y.; Li, Y. Antagonizing circRNA_002581-miR-122-CPEB1 axis alleviates NASH through restoring PTEN-AMPK-mTOR pathway regulated autophagy. Cell Death Dis. 2020, 11, 123. [CrossRef]

71. Ou, Q.; Zhao, Y.; Zhou, J.; Wu, X. Comprehensive circular RNA expression profiles in a mouse model of nonalcoholic steatohepatitis. Mol. Med. Rep. 2019, 19, 2636-2648. [CrossRef] [PubMed]

72. Guo, J.; Zhou, Y.; Cheng, Y.; Fang, W.; Hu, G.; Wei, J.; Lin, Y.; Man, Y.; Guo, L.; Sun, M.; et al. Metformin-Induced Changes of the Coding Transcriptome and Non-Coding RNAs in the Livers of Non-Alcoholic Fatty Liver Disease Mice. Cell Physiol. Biochem. 2018, 45, 1487-1505. [CrossRef]

73. Zhu, M.; Li, M.; Zhou, W.; Yang, Y.; Li, F.; Zhang, L.; Ji, G. Qianggan extract improved nonalcoholic steatohepatitis by modulating lncRNA/circRNA immune ceRNA networks. BMC Complement. Altern Med. 2019, 19, 156. [CrossRef]

74. Wan, Y.; McDaniel, K.; Wu, N.; Ramos-Lorenzo, S.; Glaser, T.; Venter, J.; Francis, H.; Kennedy, L.; Sato, K.; Zhou, T.; et al. Regulation of Cellular Senescence by miR-34a in Alcoholic Liver Injury. Am. J. Pathol. 2017, 187, 2788-2798. [CrossRef] [PubMed]

75. Yuen, M.-F.; Chen, D.-S.; Dusheiko, G.M.; Janssen, H.L.A.; Lau, D.T.Y.; Locarnini, S.A.; Peters, M.G.; Lai, C.-L. Hepatitis B virus infection. Nat. Rev. Dis. Primers 2018, 4, 18035. [CrossRef]

76. Seto, W.K.; Lo, Y.R.; Pawlotsky, J.M.; Yuen, M.F. Chronic hepatitis B virus infection. Lancet 2018, 392, 2313-2324. [CrossRef]

77. Zhang, L.; Wang, Z. Circular RNA hsa_circ_0004812 impairs IFN-induced immune response by sponging miR-1287-5p to regulate FSTL1 in chronic hepatitis B. Virol. J. 2020, 17, 40. [CrossRef]

78. Honda, M.; Kaneko, S.; Kawai, H.; Shirota, Y.; Kobayashi, K. Differential gene expression between chronic hepatitis B and C hepatic lesion. Gastroenterology 2001, 120, 955-966. [CrossRef]

79. Zhou, T.C.; Li, X.; Chen, L.J.; Fan, J.H.; Lai, X.; Tang, Y.; Zhang, L.; Wei, J. Differential expression profile of hepatic circular RNAs in chronic hepatitis B. J. Viral Hepat. 2018, 25, 1341-1351. [CrossRef]

80. Sarnow, P.; Sagan, S.M. Unraveling the Mysterious Interactions Between Hepatitis C Virus RNA and Liver-Specific MicroRNA-122. Annu. Rev. Virol. 2016, 3, 309-332. [CrossRef] [PubMed]

81. Kunden, R.D.; Khan, J.Q.; Ghezelbash, S.; Wilson, J.A. The Role of the Liver-Specific microRNA, miRNA-122 in the HCV Replication Cycle. Int. J. Mol. Sci. 2020, 21, 5677. [CrossRef] [PubMed]

82. Jost, I.; Shalamova, L.A.; Gerresheim, G.K.; Niepmann, M.; Bindereif, A.; Rossbach, O. Functional sequestration of microRNA-122 from Hepatitis C Virus by circular RNA sponges. RNA Biol. 2018, 15, 1032-1039. [CrossRef]

83. Chen, T.C.; Tallo-Parra, M.; Cao, Q.M.; Kadener, S.; Böttcher, R.; Pérez-Vilaró, G.; Boonchuen, P.; Somboonwiwat, K.; Díez, J.; Sarnow, P. Host-derived circular RNAs display proviral activities in Hepatitis C virus-infected cells. PLoS Pathog. 2020, 16, e1008346. [CrossRef] [PubMed]

84. Wong, D.K.; Yuen, M.F.; Yuan, H.; Sum, S.S.; Hui, C.K.; Hall, J.; Lai, C.L. Quantitation of covalently closed circular hepatitis B virus DNA in chronic hepatitis B patients. Hepatology 2004, 40, 727-737. [CrossRef] [PubMed]

85. Sekiba, K.; Otsuka, M.; Ohno, M.; Kishikawa, T.; Yamagami, M.; Suzuki, T.; Ishibashi, R.; Seimiya, T.; Tanaka, E.; Koike, K. DHX9 regulates production of hepatitis B virus-derived circular RNA and viral protein levels. Oncotarget 2018, 9, $20953-20964$. [CrossRef]

86. Itoh, T. Stem/progenitor cells in liver regeneration. Hepatology 2016, 64, 663-668. [CrossRef] [PubMed]

87. Zhang, J.; Xu, L.; Wang, P.; Zheng, X.; Hu, Y.; Luo, J.; Zhang, M.; Xu, M. RNA-seq Used to Explore circRNA Expression and Identify Key circRNAs During the DNA Synthesis Phase of Mice Liver Regeneration. DNA Cell Biol. 2020, 39, 2059-2076. [CrossRef]

88. Li, L.; Guo, J.; Chen, Y.; Chang, C.; Xu, C. Comprehensive CircRNA expression profile and selection of key CircRNAs during priming phase of rat liver regeneration. BMC Genom. 2017, 18, 80. [CrossRef]

89. Peralta, C.; Jiménez-Castro, M.B.; Gracia-Sancho, J. Hepatic ischemia and reperfusion injury: Effects on the liver sinusoidal milieu. J. Hepatol. 2013, 59, 1094-1106. [CrossRef]

90. Ye, Z.; Kong, Q.; Han, J.; Deng, J.; Wu, M.; Deng, H. Circular RNAs are differentially expressed in liver ischemia/reperfusion injury model. J. Cell Biochem. 2018, 119, 7397-7405. [CrossRef]

91. Qu, X.; Zheng, C.; Wang, B.; Wang, F.; Sun, X.; Gao, Y.; Xia, Q.; Kong, X. Comprehensive analysis of circular RNAs from steatotic livers after ischemia and reperfusion injury by next-generation RNA sequencing. FEBS Lett. 2020, 595, 99-109. [CrossRef]

92. Tian, X.; Hu, Y.; Liu, Y.; Yang, Z.; Xie, H.; Zhou, L.; Zheng, S. Circular RNA Microarray Analyses in Hepatic Ischemia-Reperfusion Injury With Ischemic Preconditioning Prevention. Front. Med. 2021, 8, 626948. [CrossRef] [PubMed]

93. Chen, Y.; Yuan, B.; Chen, G.; Zhang, L.; Zhuang, Y.; Niu, H.; Zeng, Z. Circular RNA RSF1 promotes inflammatory and fibrotic phenotypes of irradiated hepatic stellate cell by modulating miR-146a-5p. J. Cell Physiol. 2020, 235, 8270-8282. [CrossRef]

94. Niu, H.; Zhang, L.; Chen, Y.H.; Yuan, B.Y.; Wu, Z.F.; Cheng, J.C.; Lin, Q.; Zeng, Z.C. Circular RNA TUBD1 Acts as the miR-146a-5p Sponge to Affect the Viability and Pro-Inflammatory Cytokine Production of LX-2 Cells through the TLR4 Pathway. Radiat Res. 2020, 193, 383-393. [CrossRef] [PubMed]

95. Wang, Z.; Zhao, Y.; Sun, R.; Sun, Y.; Liu, D.; Lin, M.; Chen, Z.; Zhou, J.; Lv, L.; Tian, X.; et al. circ-CBFB upregulates p66Shc to perturb mitochondrial dynamics in APAP-induced liver injury. Cell Death Dis. 2020, 11, 953. [CrossRef]

96. Li, Y.; Gao, X.; Wang, Z.; Liu, W.; Xu, F.; Hu, Y.; Li, Y.; Shi, L. Circular RNA 4099 aggravates hydrogen peroxide-induced injury by down-regulating microRNA-706 in L02 cells. Life Sci. 2020, 241, 116826. [CrossRef]

97. Li, B. The Diagnostic Value and Mechanism of Circular RNA circMARS and circITPR1 in Anti-Tuberculosis Drug- Induced Liver Injury. Master's Thesis, North China University of Science and Technology, Tangshan, China, 2019. (In Chinese). 
98. Zhang, P.; Ming, Y.; Ye, Q.; Niu, Y. Comprehensive circRNA expression profile during ischemic postconditioning attenuating hepatic ischemia/reperfusion injury. Sci. Rep. 2019, 9, 264. [CrossRef] [PubMed]

99. Xiong, H.; Wang, H.; Yu, Q. Circular RNA circ_0003420 mediates inflammation in sepsis-induced liver damage by downregulating neuronal PAS domain protein 4. Immunopharmacol. Immunotoxicol. 2021, 43, 271-282. [CrossRef]

100. Parola, M.; Pinzani, M. Liver fibrosis: Pathophysiology, pathogenetic targets and clinical issues. Mol. Aspects Med. 2019, 65, 37-55. [CrossRef] [PubMed]

101. Tsochatzis, E.A.; Bosch, J.; Burroughs, A.K. Liver cirrhosis. Lancet 2014, 383, 1749-1761. [CrossRef]

102. Harrington, L.; McPhail, T.; Mar, V.; Zhou, W.; Oulton, R.; Bass, M.B.; Arruda, I.; Robinson, M.O. A mammalian telomeraseassociated protein. Science 1997, 275, 973-977. [CrossRef] [PubMed]

103. Barnard, A.; Moch, A.; Saab, S. Relationship between Telomere Maintenance and Liver Disease. Gut Liver 2019, 13, 11-15. [CrossRef]

104. Li, S.; Song, F.; Lei, X.; Li, J.; Li, F.; Tan, H. hsa_circ_0004018 suppresses the progression of liver fibrosis through regulating the hsa-miR-660-3p/TEP1 axis. Aging 2020, 12, 11517-11529. [CrossRef]

105. Jin, H.; Li, C.; Dong, P.; Huang, J.; Yu, J.; Zheng, J. Circular RNA cMTO1 Promotes PTEN Expression Through Sponging miR-181b-5p in Liver Fibrosis. Front. Cell Dev. Biol. 2020, 8, 714. [CrossRef]

106. Wang, W.; Dong, R.; Guo, Y.; He, J.; Shao, C.; Yi, P.; Yu, F.; Gu, D.; Zheng, J. CircMTO1 inhibits liver fibrosis via regulation of miR-17-5p and Smad7. J. Cell Mol. Med. 2019, 23, 5486-5496. [CrossRef] [PubMed]

107. Ji, D.; Chen, G.F.; Wang, J.C.; Ji, S.H.; Wu, X.W.; Lu, X.J.; Chen, J.L.; Li, J.T. Hsa_circ_0070963 inhibits liver fibrosis via regulation of miR-223-3p and LEMD3. Aging 2020, 12, 1643-1655. [CrossRef]

108. Chen, X.; Li, H.D.; Bu, F.T.; Li, X.F.; Chen, Y.; Zhu, S.; Wang, J.N.; Chen, S.Y.; Sun, Y.Y.; Pan, X.Y.; et al. Circular RNA circFBXW4 suppresses hepatic fibrosis via targeting the miR-18b-3p/FBXW7 axis. Theranostics 2020, 10, 4851-4870. [CrossRef] [PubMed]

109. Zhou, Y.; Lv, X.; Qu, H.; Zhao, K.; Fu, L.; Zhu, L.; Ye, G.; Guo, J. Differential expression of circular RNAs in hepatic tissue in a model of liver fibrosis and functional analysis of their target genes. Hepatol. Res. 2019, 49, 324-334. [CrossRef] [PubMed]

110. Zhou, Y.; Lv, X.; Qu, H.; Zhao, K.; Fu, L.; Zhu, L.; Ye, G.; Guo, J. Preliminary screening and functional analysis of circular RNAs associated with hepatic stellate cell activation. Gene 2018, 677, 317-323. [CrossRef]

111. Bu, F.T.; Zhu, Y.; Chen, X.; Wang, A.; Zhang, Y.F.; You, H.M.; Yang, Y.; Yang, Y.R.; Huang, C.; Li, J. Circular RNA circPSD3 alleviates hepatic fibrogenesis by regulating the miR-92b-3p/Smad7 axis. Mol. Ther. Nucleic Acids 2021, 23, 847-862. [CrossRef]

112. Liu, W.; Feng, R.; Li, X.; Li, D.; Zhai, W. TGF- $\beta$ - and lipopolysaccharide-induced upregulation of circular RNA PWWP2A promotes hepatic fibrosis via sponging miR-203 and miR-223. Aging 2019, 11, 9569-9580. [CrossRef] [PubMed]

113. Riaz, F.; Li, D. Non-coding RNA Associated Competitive Endogenous RNA Regulatory Network: Novel Therapeutic Approach in Liver Fibrosis. Curr. Gene Ther. 2019, 19, 305-317. [CrossRef] [PubMed]

114. Yao, J.; Dai, Q.; Liu, Z.; Zhou, L.; Xu, J. Circular RNAs in Organ Fibrosis. Adv. Exp. Med. Biol. 2018, 1087, 259-273. [CrossRef] [PubMed]

115. Chen, Y.; Yuan, B.; Wu, Z.; Dong, Y.; Zhang, L.; Zeng, Z. Microarray profiling of circular RNAs and the potential regulatory role of hsa_circ_0071410 in the activated human hepatic stellate cell induced by irradiation. Gene 2017, 629, 35-42. [CrossRef]

116. Marrone, G.; Shah, V.H.; Gracia-Sancho, J. Sinusoidal communication in liver fibrosis and regeneration. J. Hepatol. 2016, 65, 608-617. [CrossRef]

117. Carbone, M.; Neuberger, J.M. Autoimmune liver disease, autoimmunity and liver transplantation. J. Hepatol. 2014, 60, 210-223. [CrossRef]

118. Zhou, Z.; Sun, B.; Huang, S.; Zhao, L. Roles of circular RNAs in immune regulation and autoimmune diseases. Cell Death Dis. 2019, 10, 503. [CrossRef]

119. Zheng, J.; Li, Z.; Wang, T.; Zhao, Y.; Wang, Y. Microarray Expression Profile of Circular RNAs in Plasma from Primary Biliary Cholangitis Patients. Cell Physiol. Biochem. 2017, 44, 1271-1281. [CrossRef] [PubMed]

120. Liu, Y.; Li, Z.; Hao, J.; Chen, H.; Hou, T.; Hao, H. Circular RNAs associated with a mouse model of concanavalin A-induced autoimmune hepatitis: Preliminary screening and comprehensive functional analysis. FEBS Open Bio 2020, 10, 2350-2362 [CrossRef]

121. Virani, S.; Akers, A.; Stephenson, K.; Smith, S.; Kennedy, L.; Alpini, G.; Francis, H. Comprehensive Review of Molecular Mechanisms during Cholestatic Liver Injury and Cholangiocarcinoma. J. Liver 2018, 7, 231. [CrossRef]

122. Zhao, Z.; Meng, J.; Su, R.; Zhang, J.; Chen, J.; Ma, X.; Xia, Q. Epitranscriptomics in liver disease: Basic concepts and therapeutic potential. J. Hepatol. 2020, 73, 664-679. [CrossRef] [PubMed]

123. Yi, Y.C.; Chen, X.Y.; Zhang, J.; Zhu, J.S. Novel insights into the interplay between m(6)A modification and noncoding RNAs in cancer. Mol. Cancer 2020, 19, 121. [CrossRef] [PubMed]

124. Gilbert, W.V.; Bell, T.A.; Schaening, C. Messenger RNA modifications: Form, distribution, and function. Science 2016, 352, 1408-1412. [CrossRef] [PubMed]

125. Meyer, K.D.; Jaffrey, S.R. The dynamic epitranscriptome: N6-methyladenosine and gene expression control. Nat. Rev. Mol. Cell Biol. 2014, 15, 313-326. [CrossRef]

126. Chi, F.; Cao, Y.; Chen, Y. Analysis and Validation of circRNA-miRNA Network in Regulating m(6)A RNA Methylation Modulators Reveals CircMAP2K4/miR-139-5p/YTHDF1 Axis Involving the Proliferation of Hepatocellular Carcinoma. Front. Oncol. 2021, 11, 560506. [CrossRef] 
127. Pirola, C.J.; Sookoian, S. Epigenetics factors in nonalcoholic fatty liver disease. Expert Rev. Gastroenterol. Hepatol. 2020, 1-16. [CrossRef] [PubMed]

128. Xu, K.; Sun, Y.; Sheng, B.; Zheng, Y.; Wu, X.; Xu, K. Role of identified RNA N6-methyladenosine methylation in liver. Anal. Biochem. 2019, 578, 45-50. [CrossRef]

129. Joshita, S.; Umemura, T.; Tanaka, E.; Ota, M. Genetics and epigenetics in the pathogenesis of primary biliary cholangitis. Clin. J. Gastroenterol. 2018, 11, 11-18. [CrossRef] [PubMed]

130. Zhou, C.; Molinie, B.; Daneshvar, K.; Pondick, J.V.; Wang, J.; Van Wittenberghe, N.; Xing, Y.; Giallourakis, C.C.; Mullen, A.C. Genome-Wide Maps of $\mathrm{m}^{6} \mathrm{~A}$ circRNAs Identify Widespread and Cell-Type-Specific Methylation Patterns that Are Distinct from mRNAs. Cell Rep. 2017, 20, 2262-2276. [CrossRef]

131. Zhang, L.; Hou, C.; Chen, C.; Guo, Y.; Yuan, W.; Yin, D.; Liu, J.; Sun, Z. The role of N(6)-methyladenosine (m(6)A) modification in the regulation of circRNAs. Mol. Cancer 2020, 19, 105. [CrossRef] 